\title{
A Genealogy of Communicative Affordances and Activist Self-Mediation Practices
}

\author{
Bart Cammaerts
}

\section{Abstract}

In this chapter, the focus is on the various ways in which activists across time and space have appropriated traditional media - print cultures, audio and broadcasting as well as telecommunication and the internet to develop resistance practices. In doing so, I will present a historical dimension and discuss the various ways in which counter-cultures and activists have shaped information and communication technologies into tools of resistance to suit their particular needs. As such, a conceptual connection is made between the self-mediation practices of activists, communicative affordances and the mediation opportunity structure. Across various media and communication technologies, a set of affordances which enable activist mediation practices are identified. These affordances are situated at the level of 1) Temporality - linked to the affordances of asynchronous and real-time communicative practices; 2) Spatiality - related to the affordance of media and communication technologies to collapse distance, as well as enable both private and public communicative practices; and 3) Resistance - implicating the affordance to circumvent state-imposed limitations and to hack and shape technologies. It is concluded that while the Empire always strikes back, new affordances will be discovered, and new creative workarounds imagined, rejuvenating old practices as well as constituting new ones.

\section{Introduction}

Many scholars, including many contributors to this edited collection, have in recent years made valuable contributions to build conceptual bridges between media and communication studies and social movement studies. In doing so, the central role of media, of communication tools, and of self-mediation practices in the context of contentious politics has been foregrounded and better theorized. Media and communication are deemed to be crucial to assert a collective identity and circulate movement discourses, either independently or through the mainstream media, but they are equally important in terms of mobilizing efforts for direct actions and organising a movement.

In this chapter, I will provide a historical overview of the various ways in which activists and social movements have appropriated, used, and above all shaped media and communication technologies to fit a set of self-mediation practices in support of their broader movement goals. At the same time, we can also observe persistent attempts by the powers that be to limit and constrain the emancipatory potentials of media and communication technologies to act as tools of resistance. 
The broader theoretical argument that I will be making is that media and communication technologies through their appropriation by agentic actors enable a wide variety of self-mediation practices, which implicates material affordances and innovations through the creative social shaping of technology but also regulation and the dynamic interplay between the State and activists. This also relates to the permanent struggle as well as dialectic between structure and agency. Furthermore, there is also a spatial and a temporal dimension to this, whereby the precise nature of this interplay between agentic opportunities and structural constraints varies over time as well as in different (political) contexts. I will link this to a dialectic between the political opportunity structure and the mediation opportunity structure.

Self-mediation practices, communicative affordances and the mediation opportunity structure

Couldry (2004: 118) calls media practices the 'things that people do with the media'. As such, in the context of activism and social movements, self-mediation practices denote what activists do with media and communication tools in the context of their struggle. I deliberately emphasize both media and communication in this context as movements indeed produce their own media as well as aim to be represented in 'the media'. At the same time, they are also highly active communicators, directed internally within the movement and externally to the world outside of the movement. Elsewhere I have argued that activist's self-mediation practices are pivotal in the constitution of a movement and the construction of a collective identity (see Cammaerts, 2018). The self-mediation practices of social movements also fit and map onto a set of communicative goals and mediation needs, which I have suggested include: the need to disseminate movement frames, to mobilize for actions, to coordinate actions, to organize the movement, to manage its public visibility, to record protest events, and to archive protest artefacts potentially leading to movement spillovers.

Practice theory is a highly useful theoretical resource in this context precisely because it presents a distinctly dialectical theorization of the relationship between structure and agency. It sought to avoid the over-privileging of one over and above the other, which fits the study of social movements and ultimately of social change. The work of Ortner (2006) and her critiques of 'classic' practice theory is also important here. She highlighted the importance of Raymond Williams' Gramscian approach in relation to practice theory, highlighting the importance of (cultural) hegemony but also denying the possibility of total domination and closure. Equally relevant to activism and to the possibility of agency is Rao's evocation of tactics in the context of practices. Relying on de Certeau's famous distinction between the strategic and the tactical, Rao (2010: 151 - emphasis added) defines tactics as:

cunning combinations of possible practices, an opportunity that is seized upon to create an advantage. It is the act itself, ephemeral and situational, which is not in line with a dominant order. When accumulated, such acts may render structure ineffective. They are the fuzziness of everyday life that carries the potential for transformation. 
Returning to Ortner (1989, p. 192), she also boosted the historical and politicoculturalist perspective into practice theory - 'a theory of practice is a theory of history', she argued, and thus also a theory of change. A historical approach stresses the importance of a temporal dimension, of memory and tradition, but also of renewal with regards to practices. The impact of culture on practice then foregrounds the inevitability of the political and how practices are always shaped by power, inequalities, and asymmetries.

While at first focused on audiences and ordinary citizens, a practice theory approach can also be very useful to study and analyse media production or meaning making. Media practice, Ipsen (2010, p. 174) argues, is 'an activity that constitutes media meaning'. This opens up the possibility to apply a practice theory approach to what activists do with media and communication technologies in their efforts to disseminate their movement discourses and frames and to mobilize for direct action (Mattoni and Treré, 2014; Cammaerts, 2018).

It is, however, impossible to theorize the self-mediation practices of activists and social movements without acknowledging the distinct materialities of the various media and communication technologies at the disposal of activists. Objects and technologies that enable communicative practices have a set of affordances embedded in them which are amenable to certain practices and less to others. Selfmediation practices are, however, not only circumscribed by the affordances of media and communication technologies, but also by the persistent efforts to limit the emancipatory potentials of these technologies and objects by the powers that be.

Let me first address 'affordances' and how they impact self-mediation practices. Gibson (1977), an ecological psychologist, coined the notion of affordances to explain how the environment surrounding an animal constitutes a given set of affordances, which are both objective and subjective, recognized and hidden. Affordances represent opportunities or rather potentialities for a set of actions, and thus also for a set of practices.

Affordances can be objective and subjective, recognized and hidden. This means that objects can also hold affordances which have hitherto not yet been recognized as such. Furthermore, what is technologically possible, is not always intended when technologies are designed. As social constructivist perspectives on technological innovation have repeatedly pointed out, this very fact opens up a space for user resistance, for innovation and creativity; uncovering hidden affordances (Silverstone and Hirsch, 1992). This requires skills, knowledge, and know-how, although serendipity can also sometimes play a role in this regard. The appropriation of the affordances of new media and communication technologies and the potential for uncovering hidden affordances leading to innovative mediation practices is one aspect of what I called the mediation opportunity structure (Cammaerts, 2012)

Whether activists are able to exploit the communicative affordances, known as well as hidden, is not only dependent on the mediation opportunity structure, but also on 
the political and regulatory context in which activists operate. In other words, the political opportunity structure impacts on the mediation opportunity structure and shapes the horizon of the possible. What is a distinct option for activists to do or use in one context, might not possible in another, giving rise to differential activist practices in different contexts, but also innovative circumventions. As such, the appropriation of media and communication technologies by activists situates itself at the 'intersection between social context, political purpose and technological possibility' (Gillan et al., 2008, p.151).

In what follows I will address a number of communicative affordances relevant to activists, as well as the ways in which states tend to intervene to limit or thwart the emancipatory potentials of media and communication technologies.

\section{Activist Affordances, Communicative Practices and State Interventions}

The communicative practices afforded by media and communication technologies are varied and mainly situated at three levels of analysis: 1) Temporality - linked to the affordances of asynchronous and real-time communicative practices; 2) Spatiality related to the affordance of media and communication technologies to collapse distance, as well as enable both private and public communicative practices; 3 ) Resistance - implicating the affordance to circumvent state imposed limitations and to hack technologies in order to enable this.

This last set of affordances - circumvention and hacking, is necessary precisely because state but also corporate actors tend to put in place structural constraints geared towards limiting the emancipatory mediation opportunities afforded by media and communication technologies. This also refers to what is commonly called the political opportunity structure. As Meyer (2004, p.128 - emphasis in original) points out:

The wisdom, creativity, and outcomes of activists' choices - their agency - can only be understood and evaluated by looking at the political context and the rules of the games in which those choices are made - that is, structure.

If we interconnect the political with the mediation opportunity structure we can observe various structural interventions that aim to limit the agentic opportunities, but this relationship is dialectical and dynamic. As such, we also point towards evidence that agency leads to clever and creative work-arounds, circumventing the limitations put in place by the state or the market. Below, I discuss various historical examples of this dialectic in the context of different media and communication technologies and their specific affordances.

\section{Print}

The first media and communication technology enabling self-mediation practices by activists and movements was the printing press. Print cultures had both temporal and spatial affordances as they enabled the asynchronous and gradual spread of 
movement discourses and ideas through society. With technological improvements over time, printed material could be produced in vast quantities, more cheaply and it could also be distributed more easily and more widely.

In pre-revolutionary France, for example, a vibrant print-culture existed, producing an array of incendiary pamphlets and publications. It acutely demonstrated the 'dangerous power of the written word to subvert social order by entering into collective processes of political contestation', as Baker (1987, p. 208) put it. However, in order to reach the urban and rural working classes or Sansculottes, visual representations of movement frames, through for example satirical cartoons (see Figure 1), were often more important than the printed word, because those that were literate represented a minority at that time.

Figure 1: The 1789 print "The Awakening of the Third Estate"

\section{REVEIL DT TIERS ETAT:}

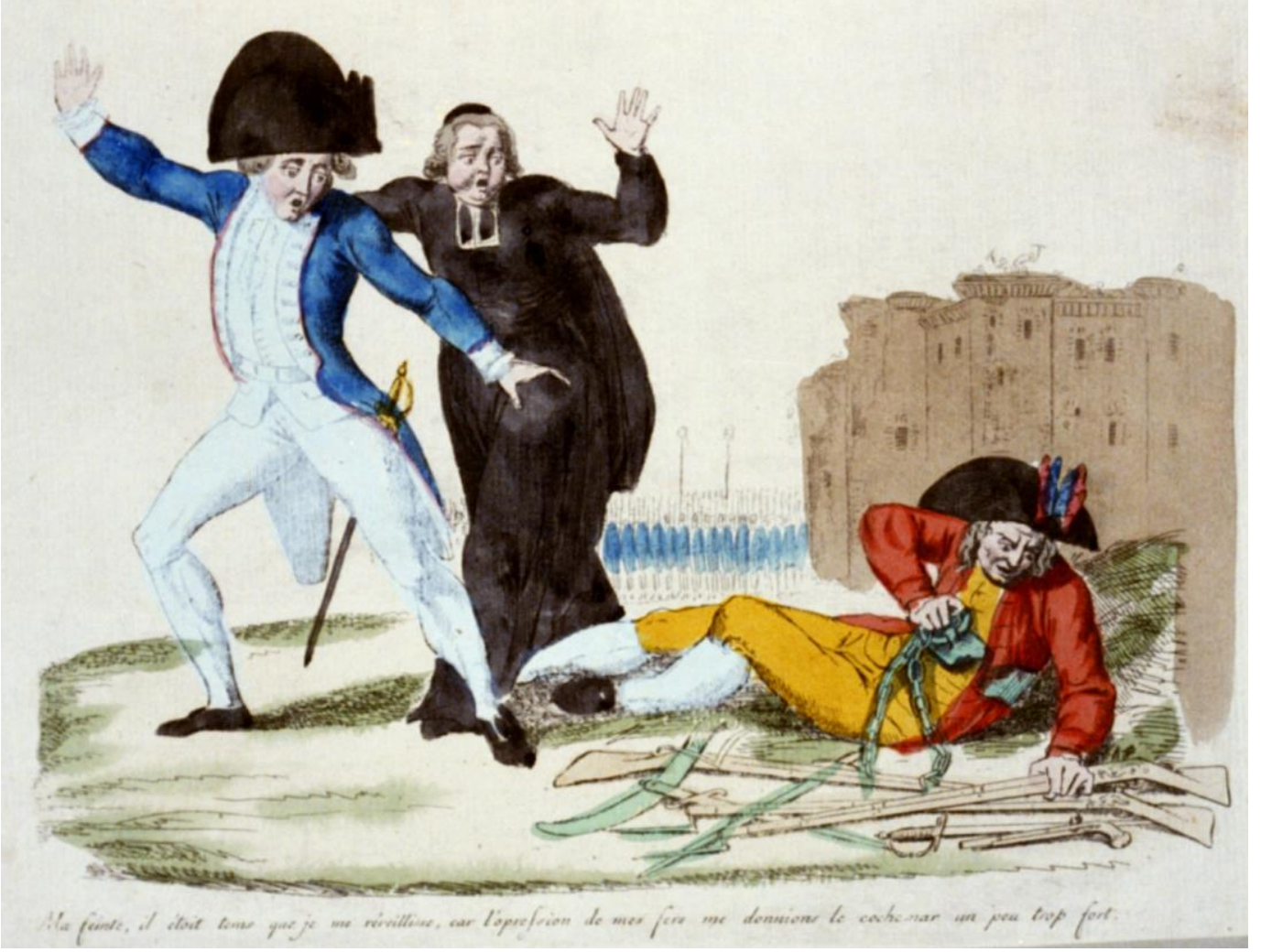

Source: Anonymous (1789) Reveil Du Tiers Etat. France, 1789. Retrieved from the Library of Congress: https://www.loc.gov/item/2009633461/

Print has remained an important form of public communication for activists and social movements throughout history as print technologies improved through numerous innovations. As evidenced by the emergence of a 'proletarian public sphere' (Negt and Kluge, 1993), these print technologies were appropriated by new movements in order to have full control over the means of communication.

This appropriation of printing technologies by both revolutionary and reformist forces did not go uncontested. States did their utmost to control the use of and access to printing technologies. In many countries, access to paper was controlled by the state 
and printers required a state license to operate. Censorship was also commonplace. On the eve of the French revolution almost 200 censors were working for the Ancien Régime and all publications needed a royal stamp of approval before they could be published officially (Darnton, 2000, p.6; Roche, 1989, p.5). Besides this, there were also mechanisms in place to censor and repress content post-publication.

Even after the demise of absolute monarchies, political and moral censorship remained firmly in place in the emerging liberal democracies, for example through seditious libel, anti-heresy, lèse-majesté, and obscenity laws. After reviewing 500 years of printing history, Steinberg (1955[1996], p.195) concluded that in terms of print, 'governments have continuously and usually successfully tried to introduce some kind of censorship while shamefacedly avoiding the odious name'.

At the same time, resistance against state control of print cultures was also rife. Despite the fervent efforts of the French state to contain subversive revolutionary content, circumvention was widespread. Printers in the Netherlands, living in a more liberal 'protestant' regime, made a fortune printing content destined to be distributed illegally in France (Eisenstein, 1997). This material would subsequently be distributed through clandestine shops and book-peddlers across France (Darnton, 1982, p.184).

Another common way of circumvention was DIY production, by-passing official printers altogether through cheap means of self-reproduction. For example, in Soviet Russia, we could observe a revival of Samizdat, a tradition of clandestine distribution of censored content which harked back to the anti-tsarist movement of the $19^{\text {th }}$ Century. Rather than print-presses, type writers were the main technology used to reproduce subversive texts. Thin and brittle carbon copy paper would be used to enable the typing of several copies at once. Samizdat is both private and public at the same time and it also represents 'a dialogical meeting of subjectivities, of the author with reader-publishers' (Komaromi, 2012, p.89).

The need for low-cost fast production and independence from official printers led the student activists of May '68 to resort to the centuries old silk-screen printing technique (Rohan, 1988). Screen printing or serigraphy was subsequently appropriated by many movements and for a long time it constituted the preferred way to reproduce textual and visual content in various underground and sub-cultures across the world (Marshall, 1983).

This tradition of DIY printing persists until today, aided by the invention of photocopying, desktop publishing, and laser printers, which together have greatly democratized the production of printed material, making state control of printed content much more difficult.

\section{Postal Services and Telecommunication}

The emergence of postal services and their affordance of sending letters 'made it possible to mobilize opinion' across large distances (Briggs and Burke, 2009, p.131). Furthermore, postal services afforded internal communication with a view to assess 
and discuss the (political) context, to coordinate the movement, and to organize direct actions, but also to exchange sensitive information.

Letters where an important means to distribute news and gossip in the run-up to the French revolution (Funck-Brentano, 1905). They also played a crucial role during the American Revolutionary War (1775-1783) when political and military leaders used letters as their main mode of communication to discuss strategies and tactics to win their independence struggle against the British (Nagy, 2011). The importance and relevance of letters in the context of activism and political struggles can also be deduced from the publication of letters written by political and intellectual leaders throughout history. A good example of this is the vast archive of letters sent by Karl Marx and Friedrich Engels (1934), to each other, but also to others within the burgeoning anarchist and socialist movement.

With the emergence of first the telegraph and later on the telephone, real-time mediated communication over longer distances became a distinct possibility. Especially the telephone with its affordance to enable real-time, one-to-one communication across large distances was ideal for coordinating a social movement across distance. The protagonists of the US civil rights protests in the 1950s and 1960s, such as Martin Luther King, but also others, amply used the telephone to coordinate actions and to distribute information amongst themselves. For the US civil rights movement, the telephone 'functioned [...] to build decentralized social formations' (Adams, 1996, p.434). We can thus also observe here how mediated communication technologies became instrumental in terms of building and sustaining movement networks.

Both in the case of the postal services and telecommunication, one of the most prevalent ways in which the state attempted to control interpersonal communication was through interception and surveillance practices. Across Europe, so-called black chamber (or cabinet noir) operations were set-up inside central post-offices. They specialised in opening, reading, and re-sealing correspondence. During the US Revolutionary War, it was estimated that about half of the correspondence between revolutionary leaders was intercepted by the British (Nagy, 2011). This practice continued well into the $19^{\text {th }}$ and $20^{\text {th }}$ Century. In their letters to each other, but also to others, Marx and Engels regularly discuss the interception of letters by police and secret services.

The telephone, however, made covert surveillance much easier and less detectable. In 1963, then US Attorney General Robert Kennedy authorized the FBI to wiretap Martin Luther King Jr.'s telephones, both at his home and in his office, transcribing everything that was said (Garrow, 1986). In the post-9/11 era, anti-terrorism laws have enabled law enforcement agencies in Western countries to massively expand their surveillance practices. In the US context, '[a]nti-war protestors, the occupy movement, Greens, and others from the left and right opposing governmental policies are surveillance targets with post-9/11 tools' (Price, 2013, np). A similar tendency can be observed in the UK (Flesher Fominaya and Wood, 2011). 
As a result of these state practices, many communicative counter-practices emerged geared towards circumventing or mitigating surveillance by the state. The letters written by leaders during the U.S. Revolutionary War were often written in code or with invisible ink (Nagy, 2011). Coded language, which ultimately led to the development of encryption, was another common response to surveillance. In one of his letters, Marx (1934) also mentions the use of secret addresses, unknown to police and secret services, to which letters could be sent safely.

When it comes to telephones, activists suspicious of eavesdropping by the state would avoid saying sensitive things over the telephone, use public telephones, or indeed also coded language. In the context of the US civil rights struggle, Wide Area Telephone Service (WATS) lines were used to distribute sensitive information safely (Stephen, 2015). These were similar to 0800-lines but paid for by organizations part of the movement. These lines would then be used by activists from the South who wanted to report aggression towards back citizens or arrests of militants, circumventing white switchboard operators. The reported information would then subsequently be conveyed further through so-called WATS-Reports.

As the example above points out, real-time telecommunication was not only used in the context of private forms of communication to coordinate decentralised movements, the telephone was also instrumental in terms of distributing alternative information and counter-discourses. Another illustration of this was how the telephone in conjunction with audio cassette tapes played a key role in the run-up to the 1979 Iranian revolution. Khomeini's speeches were transmitted through the telephone from Paris, recorded on cassette tapes in Teheran, and subsequently copied, distributed, and even amplified to large crowds. Srebreny-Mohammadi and Mohammadi (1994) spoke in this regard of 'small media' which expose the complex interconnections of private forms of communication with public ones and is illustrative of how the use of these small media could serve as a kind of gigantic megaphone.

In recent times, the emergence of the mobile phones has offered activists yet again new and different real-time communicative affordances in support of their various struggles. In a very short time, mobile technologies 'have evolved beyond simple mobile chatting devices into tools for political activity, organisation and mobilisation' (Hermanns, 2008, p.74). These are, however, also vulnerable to surveillance and jamming practices by the state. During the 2014 pro-democracy protests in Hong Kong, the affordances of mobile technologies were mobilized by the digital native protesters of the Umbrella movement, but this did not go uncontested. In response, the Chinese and Hong Kong authorities waged cyber-warfare against the prodemocracy activists, surveilling their communication and censoring online content (Tsui, 2015). Furthermore, the use of smart phones was seriously hampered in the occupied spaces, which led protesters to download FireChat, an app enabling mesh networking through Bluetooth (Monachesi and Turco, 2017). As such, they could bypass the internet and the mobile network while still able to communicate with each other, amounting to yet another creative workaround in the ongoing standoff between protesters and the powers that be. 


\section{Radio Broadcasting}

The emergence of broadcasting ushered in a new era in which public real-time communication became possible and especially radio proved to be a powerful tool in the hands of activists. Radio has the affordance of immediacy and just as with audio or visual prints, literacy is not necessary. We could in this regard refer to the role of radio during the Cuban revolution (1953-1959). Radio stations in Havana and Santiago, under the control of the Batista regime, were targeted and occupied to distribute a call for a national strike (Sweig, 2002, p.136). Furthermore, in the winter of 1958, Che Guevara set-up Radio Rebelde, a short-wave radio station located in the Sierra Maestra, a mountain range in the South of the island. Later, Castro $(2012$, p.38) wrote that the station was 'an essential tool and vehicle for the dissemination of information and, secondly, a means of communicating with the outside world'.

In the same period, the Algerian independence struggle also appropriated radio as a tool to reach mass audiences. In a very short time, radio was transformed from a hegemonic instrument in the hands of the French colonizers to an instrument of resistance. La Voix de l'Algérie Libre et Combattante, which started broadcasting in December 1956, brought 'to all Algeria the great message of the Revolution' (Fanon, 1965, p.82). Owning a radio all of a sudden became a patriotic duty. In 20 days, all the radio sets in the whole of Algeria were sold out.

The Cuban and French authorities did everything they could to disrupt the broadcasts of respectively Radio Rebelde and the Voice of Free Algeria, from jamming their radio signal to banning batteries and battery chargers, as well as seizing radio sets, or setting up black-propaganda stations (Moore, 1993; Downing et al., 2001). Censorship is, however, not always blatant and direct as was the case in Cuba and Algeria, but can also occur indirectly, through regulation, through the issuing or denying of radio licenses. The physical limitations inherent to the frequency spectrum gave state actors the opportunity to control access to the airwaves, which led in many countries to state monopolies on broadcasting or commercial networks controlling the airwaves.

This was contested in many European and US cities by pirate radio stations, circumventing regulation, and some of them establishing themselves as central nodes in the local ecology of counter cultural activities providing an important platform to a wide variety of political struggles, be they local or global (Cammaerts, 2009). It also has to be acknowledged that most, but not all, of these alternative initiatives were yet again silenced through repression, the confiscation of transmitters, or co-optation by the market. At the same time, the emergence of the internet and podcasts has enabled broadcasting for a new and much broader array of actors without needing expensive equipment or a frequency to transmit.

\section{The Internet}

As a convergent technology, the internet has presented itself as a very powerful tool enabling both real-time and asynchronous (semi-)independent communicative 
practices, as well as private and public communicative practices. One of the very first examples of the resistant affordances of the internet was its use by the Ejército Zapatista de Libéracion Nacional (EZLN) in their fight against large land-owners and the dreadful exploitation of the indigenous Maya population in Chiapas. With the help of NGOs such as the Association for Progressive Communication (APC) and activist academics, the Zapatistas built what Cleaver (1995: np) called 'an electronic fabric of struggle' (see Figure 2 for one of the many Zapatista-related websites).

Figure 2: Screenshot of http://www.ezln.org (10 December 1997)

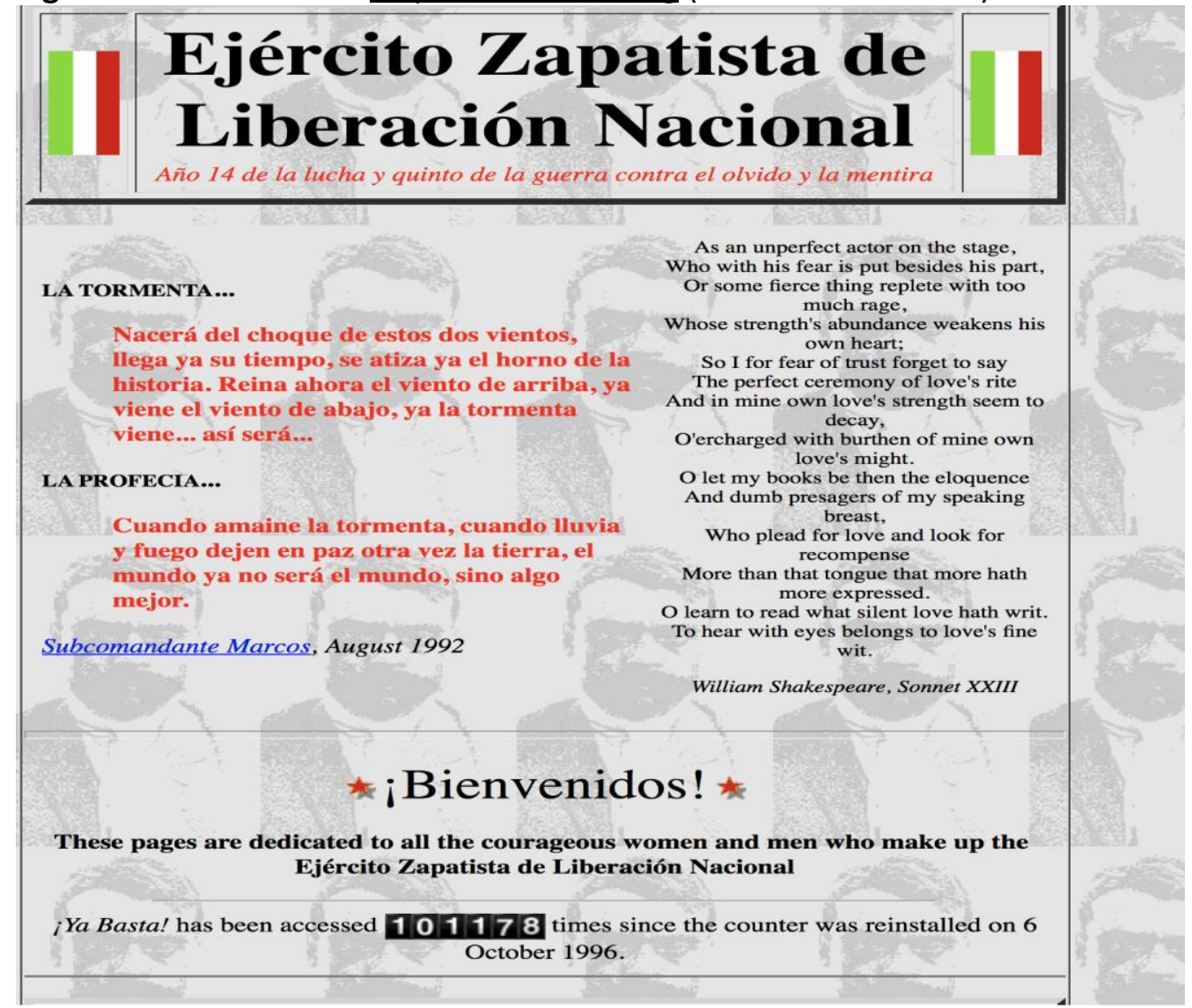

Source: Site capture by the Internet Archive - Wayback Machine on 10 December 1997. Retrieved from: https://web.archive.org/web/19971210190555/http://www.ezln.org/

The Zapatista-case demonstrated how the internet could be used by the powerless to resist and to communicate their struggle, thereby spatially extending the scope of conflict from the local to the global (Martinez-Torres, 2001). Their informational netwar not only led to a global movement in solidarity with the plight of the Maya population, but it also invited an international gaze upon the conflict in Chiapas and their struggle for indigenous rights, which arguably led to caution when it came to repression by the Mexican state.

The internet also proved to be potent in terms of coordinating and mobilising for direct actions in the offline world. We could refer here to the profuse use of online forums, chat and mailing lists to organise and coordinate the so-called 'Battle of Seattle' in 1999 (Kellner and Best, 2004). To the great surprise of security forces about 50.000 protesters managed to disrupt and even shut down an official WTO-summit. 
This successful protest 'became a symbol and battle cry for a new generation of activists, as anti-globalization networks were energized around the globe' (Juris, 2005, p.195). The anti-WTO protests in Seattle also gave rise to Independent Media Centers (IMCs), commonly known as Indymedia - semi-independent entities providing informational infrastructures for a variety of struggles to self-represent themselves and to mobilise for direct action (Cammaerts, 2005).

The emergence and success of proprietary social media platforms has in the meantime significantly altered the ways in which activists and social movements communicate, organise and mobilise online (see a.o. Gerbaudo, 2012). Whereas websites and independent means of communication still exist, much of this has shifted to social media platforms such as Twitter and Facebook, which combine real-time and asynchronous communicative affordances within their platforms and also enable the transnationalization of struggles. The Arab Spring protests (2010), the Indignados and Occupy movement (2011), as well as the Gezi Park protests in Turkey (2013) are all examples of how activists have used social media platforms in a very productive manner to mobilize and coordinate mass protests, replacing mailing lists and movement-platforms such as Indymedia or ProtestNet. This is also an example of what could be called spatially mediated movement spillovers.

The reaction by states, but increasingly also by corporate actors controlling the means of communication, against the enormous emancipatory potential of the internet, are unsurprisingly very similar to the ones discussed in the historical examples above: censorship, surveillance, jamming, repression, disruption, and counter-propaganda. Today, almost all countries, but also corporate actors and public institutions such as schools, filter the internet and censor content online in some way or another. Many bloggers worldwide have been prosecuted, fined, and/or jailed for what they have written online.

It is in this regard common to single out authoritarian regimes, especially in Asia and the Middle East, for their filtering and repressive practices (Zittrain et al., 2017), but similar practices, albeit less extreme and with different justifications, are also enacted in the so-called liberal West. We could refer here to the blocking of Pirate Bay and similar sites enabling peer-to-peer sharing of copyright protected digital content or the repression against members of Anonymous (Wesselingh, 2014; Earl and Beyer, 2014). Besides this, corporate actors are also increasingly implicated in efforts of Western states to limit access to what is called 'online terrorist content'. In June 2017, Facebook, Microsoft, Twitter, and YouTube formed the Global Internet Forum to Counter Terrorism, formalizing ongoing collaborations between these companies, governments and supra-national bodies to 'make our hosted consumer services hostile to terrorists and violent extremists' (Twitter, 2017). But just as with the surveillance practices mentioned above, more legitimate activists and movements are also the victim of this hostile environment policies. We could refer here again to the repression against WikiLeaks/Anonymous or the sudden removal of several antiausterity groups by Facebook in 2011 (see Cammaerts, 2018). 
Just as was the case throughout history, activists have also been creative and innovative in terms of hacking technologies to enable circumvention in an online context. This has given rise to the notion of hacktivism or 'activism gone electronic' (Jordan and Taylor, 2004, p.1). Hacktivismo, a sub-division of the hacker collective The Cult of the Dead Cow, for instance, developed several tools based on the onion routing technology (ToR) to enable activists to conceal their identity and IP-address when browsing, chatting, or emailing. VPN connections enable, in some contexts, to bypass local censorship of content and activists can also rely on powerful encryption technologies to protect content they wish to keep secret when communicating online.

This also shows that the internet is not merely facilitative, but also constitutive of protest and direct action. In this regard, we could refer to the ways in which the internet itself has become a versatile weapon in the hands of activists. The abovementioned hacker collective Anonymous, for example, connects dispersed members and organizes Distributed Denial of Service (DDoS) attacks against a common target or hacks servers to extract information. They targeted a variety of ideological enemies such as Scientology, European fascist parties, the Klu Klux Klan, and more recently Daesh.

Finally, we can also discern a burgeoning movement which explicitly focusses on internet rights and advocates for a radical freedom of information, unfettered communication, and strong privacy protections. We could refer in this regard to the emergence of Anonymous, WikiLeaks, and Pirate Parties (Beyer, 2014).

\section{Conclusion}

Distinct media and communication technologies and infrastructures such as print presses, postal services, telephone, broadcasting and more recently the internet have afforded a variety of mediation practices to activists relevant to their various struggles and in line with a set of mediation needs. These mediation practices thus link up with a set of mediation logics, such as the need to distribute movement discourses, to mobilize for direct actions, to coordinate internally, to produce and archive protest artefacts, as well as circumvent state regulation and repression. The temporal, spatial, and resistant affordances of media and communication technologies enable a set of agentic opportunities which impact differentially on the various mediation logics.

However, these agentic opportunities are not merely circumscribed by the affordances inherent to technologies and by technological innovations giving rise to new affordances. The political context and how it reacts to limit the agentic opportunities which media and communication technologies afford is also of importance here. This political opportunity structure also has a temporal/historical and a spatial/contextual dimension. Activists in certain contexts have to contend with different kinds of constraints and opportunities than those in others, but at the same time, it is clear from our analysis that all nation states, but also corporate actors, have always intervened, in subtle as well as less subtle ways, when it comes to media and communication technologies. 
The political opportunity structure never fully controls or contains the mediation opportunity structure, but the mediation opportunity structure is not fully autonomous either; the Empire always strikes back. In spite of this, when considering the history highlighted above, we can be certain that new technologies will be developed, new affordances discovered, and new creative workarounds imagined, rejuvenating old practices as well as constituting new ones. These might be temporal or short-lived, but they will facilitate and shape political struggles across the world. Furthermore, let us not forget that ' $[t]$ he power of the media resides in the capacity to reactivate memories of the revolutionary past' (Briggs and Burke, 2009, p.88). Long may it continue!

\section{References:}

Adams, P. C. (1996). Protest and the scale politics of telecommunications. Political Geography 15(5), 419-41.

Baker, K. M. (1987). Politics and Public Opinion Under the Old Regime: Some Reflections. In J. R. Senser and J. D. Popkin (eds). Out of Print: Press and Politics in Pre-Revolutionary France (pp. 204-46). Berkeley, CA: University of California Press.

Beyer, J. L. (2014). The Emergence of a Freedom of Information Movement: Anonymous, WikiLeaks, the Pirate Party, and Iceland. Journal of Computer-Mediated Communication 19(2), 141-54.

Briggs, A. and Burke, P. (2009). A Social History of The Media: From Gutenberg to the Internet. Cambridge: Polity Press.

Cammaerts, B. (2005). ICT-Usage among Transnational Social Movements in the Networked Society - to organise, to mobilise and to debate. In R. Silverstone (Ed.). Media, Technology and Everyday Life in Europe: From Information to Communication (pp. 5372). Aldershot: Ashgate.

Cammaerts, B. (2009). Community Radio in the West: A Legacy of Struggle for Survival in a State and Capitalist Controlled Media Environment, International Communication Gazette 71(8), 1-20.

Cammaerts, B. (2012). Protest Logics and the Mediation Opportunity Structure. European Journal of Communication 27(2), 117-34.

Cammaerts, B. (2018). The Circulation of Anti-Austerity Protest. Basingstoke: Palgrave-MacMillan. Castro, F. (2012). La victoria estratégica. La contraofensiva estratégica. Madrid: Ediciones Akal.

Cleaver, H. (1995). The Zapatistas and the Electronic Fabric of Struggle. Retrieved from: https://la.utexas.edu/users/hcleaver/zaps.html [Last consulted 15 February 2019].

Couldry, N. (2004). Theorising media as practice. Social Semiotics 14(2): 115-32.

Darnton, R. (1982). The Literary Underground of the Old Regime. Cambridge, MA: Harvard University Press.

Downing, J. D., with Ford V. T., Gil, G. and Stein, L. (2001). Radical Media: Rebellious Communication and Social Movements. London: Sage.

Earl, J. and Beyer, J. L. (2014). The Dynamics of Backlash Online: Anonymous and the Battle for WikiLeaks. In L. M. Woehrle (Ed.). Intersectionality and Social Change (pp. 207-33). Bingley: Emerald Group Publishing Limited.

Eisenstein, E. L. (1997). The Printing Press as an Agent of Change: Communications and Cultural Transformations in Early-Modern Europe. Cambridge: Cambridge University Press.

Fanon, F. (1965). The Wretched of the Earth. New York, NY: Grove Press, Inc.

Flesher Fominaya, C. and Wood, L. (2011). Repression and social movements. Interface: a journal for and about social movements 3(1), 1-11.

Funck-Brentano, F. with P. D’Estrée (1905). Les Nouvellistes. Paris: Hachette. 
Garrow, D. (1986). Bearing the Cross: Martin Luther King Jr. and the Southern Christian Leadership Conference. New York: Harper Collins.

Gerbaudo, P. (2012). Tweets and the Streets: Social Media and Contemporary Activism. London: Pluto Press.

Gibson, J. J. (1977). The Theory of Affordances. In R. Shaw and J. Bransford (eds) Perceiving, Acting, and Knowing: Toward an Ecological Psychology (pp. 67-82). Hillsdale, NJ: Lawrence Erlbaum Associates.

Gillan, K., Pickerill, J. and Webster, F. (2008). Anti-War Activism: New Media and Protest in the Information Age. Basingstoke: Palgrave Macmillan.

Hermanns, H. (2008). Mobile Democracy: Mobile Phones as Democratic Tools. Politics 28(2), 7482.

Ipsen, G. (2010). Communication, Cognition and Usage: Epistemological Considerations of Media Practices and Processes. In B. Bräuchler and J. Postill (eds) Theorising Media and Practice (pp.171-90). Oxford and New York, NY: Berghahn.

Jordan, T. and Taylor, P. A. (2004). Hacktivism and Cyberwars Rebels with a cause? London: Routledge.

Juris, J. S. (2005). The New Digital Media and Activist Networking within Anti-Corporate Globalization Movements. The Annals of the American Academy of Political and Social Science 597, 189-208.

Kellner, D. and Kahn, R. (2004). New Media and Internet Activism: From the 'Battle of Seattle' to Blogging. New Media \& Society 6(1), 87-95.

Komaromi, A. (2012). Samizdat and Soviet Dissident Publics. Slavic Review 71(1), 70-90.

Martinez-Torres, M. E. (2001). Civil Society, the Internet, and the Zapatistas. Peace Review: A Journal of Social Justice 13(3), 347-55.

Marx, K. and Engels, F. (1934). Correspondence 1846-1895: A Selection with Commentary and Notes. London: Lawrence and Wishart Ltd.

Mattoni, A. and Treré, E. (2014). Media practices, mediation processes, and mediatization in the study of social movements. Communication Theory 24 (3), 252-271.

Meyer, D. S. (2004). Protest and Political Opportunities. Annu. Rev. Sociol. 30, 125-45.

Monachesi, P. and Turco, M. (2017). New Urban Players: Stratagematic Use of Media by Banksy and the Hong Kong Umbrella Movement. International Journal of Communication 11(2017), 1448-65.

Moore, D. (1993) Revolution! Clandestine Radio and the Rise of Fidel Castro, Monitoring Times, April.

Nagy, J. A. (2011). Invisible Ink: Spycraft of the American Revolution. Yardley, PA: Westholme Publishing.

Negt, O. and Kluge, A. (1993). The Public Sphere and Experience: Toward an Analysis of the Bourgeois and Proletarian Public Sphere. Minneapolis, MN: University of Minneapolis Press.

Ortner, S. B. (1989). High Religion: A Cultural and Political History of Sherpa Buddhism. Princeton, $\mathrm{NJ}$ : Princeton University Press.

Ortner, S. B. (2006). Anthropology and Social Theory: Culture, Power and the Acting Subject. Durham, NC: Duke University Press.

Price, D. (2013, 9 August). A Social History of Wiretaps. Counterpunch. Retrieved from: https://www.counterpunch.org/2013/08/09/a-social-history-of-wiretaps-2/

Rao, U. (2010). Embedded/Embedding Media Practices and Cultural Production. In B. Bräuchler and J. Postill (eds) Theorising Media and Practice (pp 147-68). Oxford and New York, NY: Berghahn.

Roche, D. (1989). Censorship and the Publishing Industry. In R. Darnton and D. Roche (eds) Revolution in Print: The Press in France, 1775-1800 (pp. 3-26). Berkeley, CA: University of California Press.

Rohan, M. (1988). Paris '68: graffiti, posters, newspapers and poems of the events of May 1968. London: Impact. 
Silverstone, R. and Hirsch, E. (1992). Consuming Technologies: Media and Information in Domestic Spaces. London: Routledge.

Sreberny-Mohammadi, A. and Mohammadi, A. (1994) Small Media, Big Revolution: Communication, Culture, and the Iranian Revolution. Minneapolis, MN: University of Minnesota Press.

Steinberg, S. H. (1955 [1996]). Five Hundred Years of Printing. London: The British Library.

Stephen, B. (2015, October). How Black Lives Matter Uses Social Media to Fight the Power. Wired. Retrieved from: http://www.wired.com/2015/10/how-black-lives-matter-usessocial-media-to-fight-the-power/

Sweig, J. E. (2002). Inside the Cuban Revolution: Fidel Castro and the Urban Underground. Cambridge, MA: Harvard University Press.

Tsui, L. (2015). The coming colonization of Hong Kong cyberspace: government responses to the use of new technologies by the umbrella movement. Chinese Journal of Communication $8(4), 447-55$.

Twitter (2017, 26 June). Global Internet Forum to Counter Terrorism. Twitter Public Policy. Retrieved from: https://blog.twitter.com/official/en us/topics/company/2017/GlobalInternet-Forum-to-Counter-Terrorism.html

Wesselingh, E. M. (2014). Website Blocking: Evolution or Revolution? 10 Years of Copyright Enforcement by Private Third Parties. Revista de Internet, Derecho y Política 19 October: 35-47.

Zittrain, J., Faris, R., Noman, H., Clark, J., Tilton, C. and Morrison-Westphal, R. (2017). The Shifting Landscape of Global Internet Censorship. Cambridge, MA: Berkman Klein Center for Internet \& Society. 